\title{
DETERMINED TO LEARN: ACCESSING EDUCATION DESPITE LIFE- THREATENING DISASTERS
}

\author{
Claudine SchWeber, Ph.D. \\ Professor, Graduate School of Management \& Technology \\ University of Maryland University College
}

\begin{abstract}
The 'right to education' proclaimed by the 1948 Universal Declaration of Human Rights requires access to learning as well as the support systems. Since access can be interrupted by various circumstances, the possibility of providing continuity despite external dangers by using online distance education, offers an intriguing and valuable option. For example, life-threatening disasters, such as war or hurricanes, can interrupt or halt ongoing higher education coursework. Despite that reality, some students remain determined to continue the learning. How can institutions respond to this determination fast enough to be of use and effective enough to maintain their educational reputations? Empire State College's (New York) activities in its Lebanon Residence Program after the 2006 war and Xavier University in New Orleans' actions in the aftermath of Hurricane Katrina provide valuable answers. Together with the unique Sloan Semester — created to temporarily provide educational continuity for hurricane affected students - these programs also offer lessons on resilience and survival in a crisis.
\end{abstract}

\section{KEY WORDS}

Educational Access, Distance Learning, E-Learning, Higher Education and Disaster, Resilience, Sloan Semester, Educational Continuity, Crisis Management, Academic Continuity

\section{INTRODUCTION}

In 1948, the United Nations passed the Universal Declaration of Human Rights which included a statement about the critical importance of education. Article 26 states, in part, that:

Everyone has the right to education...higher education shall be equally accessible to all on the basis of merit...

Article 26(1), Universal Declaration of Human Rights, United Nations (December 10, 1948)

Developments in technology at the end of the $20^{\text {th }}$ century have expanded the possibilities for accessing that Right due to the use of the internet for online distance education. Two recent events show how this Right has been pursued despite seriously adverse conditions: the 2005 Hurricane disaster in the southeastern United States and the 2006 war between Lebanon and Israel. Despite being surrounded by life-threatening disasters such as war, hurricane, floods some students were determined to continue their education. Given the dangers in the surrounding environment, online education was the only real option. For the higher education institutions involved, the question was how could they respond to this determination for access fast enough to be of use and effective enough to maintain their educational 
reputations? Their response and that of the learning community offers a model for others to seriously consider.

An early example of distance learning as a solution in the face of danger comes from France, where even WWII was not enough to stop the educational process. Once war was declared in September 1939, the national education minister lobbied the French president to create a structure so that education could continue. In December 1939, the National Center for Distance Education (CNED) was established by decree as a "temporary measure during the hostilities" to provide correspondence courses which would follow the same program, methods used in the schools and with the same instructors. This 'temporary' arrangement turned out to be permanent-CNED today is an institution with over 350,000 students [1, pp. 2, 9-10].

Almost seven decades later, in the summer 2006, war was once again the impetus for providing educational continuity, but this time with a significant difference: technology enabled learning via the internet was the medium of communication and learning. In Lebanon and Israel ${ }^{1}$, educational institutions dealt with the unexpected and dangerous environment by providing online courses for students impacted by the missiles and bombs. In Lebanon, Empire State College (New York) redesigned its onsite residency programs using multi-media and online technology [2].

In the United States, another type of disaster-hurricanes-resulted in the use of online learning to continue education. Hurricane Katrina hit the gulf coast and New Orleans in particular, at the end of August 2005. Hurricane Rita, less severe, followed a few weeks later. Integral to the crisis management strategy in the gulf coast region was the Sloan Semester project. Using the online courses in the Sloan Semester database, students from Louisiana and Mississippi colleges were able to continue their education regardless of their location. The Sloan Semester project was a unique electronic partnership between 153 higher education institutions, the Southern Regional Education Board ${ }^{2}$ and the Sloan Foundation [3a].

This paper will explore how these institutions organized and implemented an e-learning strategy for dealing with their disaster, enabling the students to continue their education: Lebanon-Empire State College's programs with the American University of Technology in Halate and Tripoli, and the American University of Science and Technology in Beirut and Zenle; United States-Xavier University in New Orleans provided continual electronic updates on the web about its recovery actions, future registration, credit transfer, and supported students taking online courses. Since the disasters occurred in different countries under different circumstances, these cases offer an opportunity to examine their strategies for surviving, and to consider how higher education can be resilient when faced with disaster in order to provide continued access to education.

In both cases the educational institutions were confronted with a crisis: the disaster or the extent of its reach was a surprise; the situation needed immediate attention and action; the outcome could seriously

\footnotetext{
${ }^{1}$ In Israel, MEITAL_the inter-university centre for e-learning-coordinated online support for students and faculty in the north from some of its 15 member institutions (for example, Bar Ilan University provided courses, Askelon/ Sfad College,Tel Chai College) during the war. Sufficient information for discussion was not available at this time. Meital: the inter-university centre for e-learning. http://meital.iucc.ac.il; conversations and email with Gila Kurtz, Director of E-Learning, Bar-Ilan University (October 2006-October 2007)

2 The Southern Regional Education Board (SREB) Electronic Campus is a web portal of online courses and programs primarily from southern US colleges and universities. SREB infrastructure was the online backbone for the Sloan Semester students to select and register for courses [3b, p. 2].
} 
damage the institution's reputation; both the events and solutions were out of the students' and administrations' complete control [4]. Moreover, this situation meant that some options could only be devised as the conditions evolved. Thus, the paradox: "only by going forward [was] it possible to learn what the options [were] for going forward” [5, p. 526].

\section{ACCESSING EDUCATION: LEBANON AND NEW ORLEANS, USA}

\section{A. Lebanon}

The Lebanon Residency Program at Empire State College (New York) is one of two international programs that combine online and onsite instruction. The Lebanon program started in Cyprus (1997) and moved to Lebanon (2004), as part of the junior and senior years in a Bachelor of Science degree. The Empire State College (ESC) program serves students at the American University of Technology and the American University of Science and Technology; students from other Middle East institutions may also be enrolled. Concentrations include: business, hotel management, marketing, information systems, and computer science. The program involves 18 week semesters, with a ten day residency led by US based faculty on site in Lebanon once each semester. ${ }^{3}$ The remaining coursework is done online. Typically, there are 200-300 students and 20 faculty in each semester $[2,6]$.

When war broke out in the summer 2006, ESC realized that faculty could not travel to Lebanon for the fall residency. To enable the courses and learning to continue, ESC created a 'virtual residency' using multimedia, by videotaping the faculty; burning DVDs of the faculty lectures; and, shipping the DVDs to the two Lebanese universities. Local students viewed the videos at the two partner institutions; those outside of Lebanon received individual copies. In-depth interaction was supported/ supplemented by email, chat, and telephone. The Lebanon program was able to continue in fall 2007 and beyond. The recovery from the war environment and the change from the onsite-residency model appears due to several factors: they quickly moved to work with their educational partners to establish a home base for the alternate learning mode (DVD); their experience with technology, in the form of online courses, meant students and faculty were comfortable with technology-based learning; this comfort also enabled the transformation of the face-to-face learning to DVD lectures by the instructors; they developed and implemented an effective communication system by using established channels and opening some new ones.

Karolyn Andrews, Lebanon Program Director, summed up the spirit of their educational determination when confronted by unexpected disaster: The Empire State College degree "provides options for our students; the war just made those options more critical.” This could be the anthem for many others [2, email January 25, 2007].

\section{B. New Orleans}

Xavier University of Louisiana is a historically black and Catholic college with approximately 3000 fulltime students specializing in pharmacy, arts and sciences, and graduate programs in education, counseling and psychology.

Hurricane Katrina hit the U.S. gulf coast (Louisiana, Mississippi) and New Orleans August 29, 2005. When it left the area just three days later thousands were dead or homeless. Colleges and universities in

\footnotetext{
${ }^{3}$ Note: There has been no onsite residency in the Lebanon program since the 2006 war.
} 
the gulf coast were severely damaged. Xavier University's (XU) buildings filled with 4-6 feet of water, resulting in destruction of the physical plant, mildew and toxic mold in the Library and other buildings, and the displacement of faculty and staff to northern Louisiana cities, Texas, and to the sister Catholic institution, Xavier University in Cincinnati, Ohio. Students were also scattered. XU was able to recover sufficiently to re- open January 17, 2006 for the spring term, with approximately 75\% of the original fall 05 enrollment (3091 students) [7b].

XU's emergency website, set up in southern California three months earlier, was activated when staff and students left the Xavier grounds a few days before the storm touched down. This provided basic information. In addition, back-up tapes which had been housed at a data storage facility were collected, brought to and eventually hosted by Xavier University in Cincinnati which enabled communication by website and email. Thus, alongside the activated emergency web site, more dynamic outward communication was established. By mid-October 2005, and bi-weekly thereafter, the University Newsletter posted renovation details, photos of campus clean-up status, interviews with students "eager to return", progress towards the January 2006 re-opening, class schedules for the repeat fall semester, reports on fundraising and repair plans, details of registration procedures, cancelled courses, spring semester information and more [7c; 8, email October 24, 2007)].

Xavier's recovery was due, in part, to two factors: first, about $40 \%$ of the returning spring semester students had enrolled in coursework at other campuses or online in fall 05; of these, one-third (418) took one or more courses through the Sloan Semester Program. This number was substantially more than at any other Louisiana or Mississippi institution [3a]. This continued connection with education, despite difficult circumstances, indicates a strong determination to learn within Xavier University. The online environment was so effective for the fall 05 that the graduate education program was offered totally online during Spring 2006, allowing the department and students sufficient time re-organize for Fall ' 06. Second, Xavier was technologically prepared. The emergency web site in California had been established in May 2005. The back-up tapes were housed at a data storage facility rather than in a nearby building, as was the case with some institutions. Xavier officials could then implement various communication methods quickly [8].

\section{ACCESS TO EDUCATION AND INSTITUTIONAL RESILIENCE}

The actions of Empire State College (ESC) in Lebanon and Xavier University (XU) in New Orleans reflect characteristics commonly associated with resilient organizations which involve an adherence to several principles. These are the ability to:

- Adapt to the unexpected situation and problem-solve, developing solutions out of what's available. This is sometimes called 'bricolage': developing solutions out of existing conditions and being creative under pressure;

- Expand upon existing resources or obtain access to resources beyond those normally available (in this case, online-distance medium);

- Make decisions quickly "in unfamiliar contexts” when faced with the disasters [5, p. 525]; and

- Manage effectively in situations of uncertainty [9, references Karl Weick on bricolage].

The point, of course, is to be effective in managing the crisis so that operations can be resumed and lessons learned for the future [10]. Moreover, from the student perspective, academic continuityteaching and learning-is critical if access to education is to continue. 
As we consider how Empire State College and Xavier University applied the four principles, you may recognize the relevance, indeed similarity, to resilience by individuals. ESC and XU were able to:

- Adapt to the situation and problem-solve. In the Lebanon program, this meant halting the forthcoming faculty on-site residency and finding other ways to communicate and teach the material that typically occurred in that period. It also meant communicating with students about plans and actions so that they knew they could continue to access the program and complete their degree. New Orleans communicated with stakeholders (such as students, parents, faculty and staff, other universities), supported students who took courses off campus and online via the Sloan Semester, began considering what would be needed to open in the spring while adjusting for Fall ' 05.

- Expand upon existing resources. In Lebanon, students and faculty were already comfortable with online-distance learning. ESC expanded on that model by having faculty develop lectures, transferring that to DVD format, mailing them to individuals and the two partner institutions. In New Orleans, XU worked with their sister institution in Cincinnati to run the back-up tapes, activated the emergency website, worked out ways in which students and faculty could use facilities of neighboring universities (Tulane and Loyola) for the spring term if needed and contacted financial supporters for the rebuilding projects.

- Quickly make and implement decisions. Both ESC and XU decided that classes would resume the semester following the disaster and communicated that information to various parties. Both quickly began developing the needed adjustments, such as crafting DVDs, agreeing to start the spring term to coincide with Tulane and Loyola schedules, accepting the OctoberMarch Sloan Semester time frame. Xavier also activated its emergency site and picked up the back-up tapes from storage before the storm hit on August 29.

- Manage effectively in uncertain and unexpected situations. In the Lebanon program, students were able to continue their degree coursework in fall 06 because ESC had been actively communicating with students and staff, using established networks, and applying a technological solution to some of the difficulties. At Xavier, the pattern was the same: the new semester began in January 2006 as planned, communication with stakeholders (students, parents, employees, and foundations, repair teams, government entities) was ongoing, collaborations and assistance was developed with Tulane and Loyola Universities in the area as well as Xavier in Cincinnati; technology was critical to the communication process as well as the courses.

\section{A. The Sloan Semester}

The Sloan Semester project was so integral to supporting accessibility to education during the USA disaster that in the best spirit of 'bricolage', it is a model for crisis management in the face of adversity. The intent of the Sloan Semester was that online coursework would be an educational 'bridge' for students in the affected areas who would take course(s) offered by a variety of institutions which would be applied to their home campus. This would allow for educational continuity for the students, and give the affected institutions time to re-organize. Course options were listed in the SREB website. Eventually, about 1700 students registered in 1345 courses offered free by 153 institutions [3b, pp. 1-2].

This program was created very quickly to fill the educational gap faced by students who had registered for fall classes in the Hurricane Katrina affected areas and were now disconnected. Within 72 hours of Katrina's landfall, a team representing the Sloan-C Consortium, the Sloan Foundation and educational institutions had obtained funding to support online coursework by students in the affected areas. Five days later, a website announcing the program was operative, and notices were sent to listservs and related links. In the interim, policies, rules and responsibilities for students and provider institutions had been established. Students would not be charged for their courses, since they had already paid Fall 2005 
tuition; higher education institutions which contributed courses to the project would receive a course fee depending on the number of enrollments; courses would run October 2005-March 2006. Shortly thereafter, institutions that were contributing courses could submit their list to the database sponsored by SREB which became the Sloan Semester catalogue. By September 15-two weeks after the first discussions and grant approval by the Sloan Foundation - the catalogue and system was live [3b]!

The Sloan Semester project may be replicable in other countries faced with unexpected disasters that affect higher education. It requires an existing collaborative network of educational institutions, creative technology expert(s) who consider new possibilities and opportunities and can be detailed to this project for several weeks, the ability to move quickly for funding and operational processes once the decision to go ahead has been made, and skills to quickly negotiate agreements with educational institutions. Such a project also requires a comfort with identifying options and selecting among them as the process evolves - that is, operating and acting in an environment of uncertainty and opportunity.

\section{FINAL COMMENTS EDUCATIONAL ACCESS-PERSISTENCE DESPITE DISASTER}

In the first paragraph of this document, this question was posed: "how can institutions respond to [the] determination for access [to education] fast enough to be of use and effective enough to maintain their educational reputations? Empire State College and Xavier University provided some answers. In adhering to several principles associated with resilience and survival, they communicated quickly and honestly with the various stakeholders; they built upon existing technological systems and the digital environment such as online learning, a strong information technology infrastructure, multi-media, and chat to provide new or varied services in the immediate and longer-term aftermath; they collaborated with or expanded upon existing support networks; they moved quickly in deciding upon and implementing actions, and revised or developed creative solutions as the situation unfolded. These higher education institutions, and the unique Sloan Semester, provide evidence for the claim that "only by going forward, is it possible to learn what the options are for going forward” [5, p 526)]. Which they did.

\section{ACKNOWLEDGEMENTS}

The author wishes to thank Ms. Karolyn Andrews who directs the Lebanon Residency Program at Empire State College and Ms. Catherine Lewis, who directs the technology activities at Xavier University for their willingness to respond quickly to my emailed questions. Ms. Andrews eloquently captured the essence of access to education (quote p. 3).In a discussion September 2006 in New Orleans, Ms. Lewis first pointed out the obvious: place the IT emergency back-up system far away from the campus (Xavier had one in California), not in the building next door or the nearby community. It hadn't been obvious to some other colleges.

\section{REFERENCES}

1. Bourrel, J. Les CNED ou les distances effaces: La Revue due Centre National d'enseignement a distance. CNED, Ministere de la jeunesse, de l'education nationale et de la recherece, 2003.

2. Andrews, K. Director of Empire State College, Lebanon Residency Program. Email correspondence (January-October 2007).

3. a. Sloan-C. Sloan Semester: Summary http://www.sloan-c.org/sloansemester/index.asp. b. Sloan-C. Special Report: http://www.sloan-c.org/publications/books/pdf/SloanSemester.pdf.

4. Pearson, C. M. \& I. L. Mitroff. From crisis prone to crisis prepared: A framework for crisis management. Academy of Management Executive 7(1): 48-59, 1993. 
5. Winter, S. Developing Evolutionary Theory for Economics and Management. In K. Smith and M. Hitt (eds.), Great Minds in Management, 209-546. Oxford University Press, 2006.

6. Empire State College: International Program-Lebanon Residency Program. http://www.esc.edu/ESConline/esc_locations/internat.nsf/whole.

7. Xavier University. http://www.xula.edu.

a. http://www.xula.edu/institutional-advancement/tmax_october05.htm.

b. http://www.xula.edu/institutional-advancement/Webpage_News_Katrina.html.

c. http://www.xula.edu/institutional-advancement/Recovery1.htm.

8. Lewis, C. Vice-President, Office of Technology Administration, Xavier University. Email correspondence and personal discussions (September 2006-October 2007).

9. Mallak, L. Putting Organizational Resilience to Work. Industrial Management 40(6): 8-13, Nov/Dec 1998.

10. Pearson, C. M. \& J. Claire. Reframing Crisis Management. Academy of Management Review 23(1): 59-77, January 1998.

\section{ABOUT THE AUTHOR}

Claudine SchWeber, Ph.D. is currently Professor of Management in the Doctor of Management program, University of Maryland University College. She focuses on organizational change, conflict resolution, leadership. As Associate Provost for Distance Education \& Lifelong Learning at UMUC, two Centers were developed-Intellectual Property in the Digital Environment and Accessibility in Distance Education-with grants from the Sloan Foundation, NEC Bell Atlantic, Verizon. She is currently researching educational access, resilience and survival and has previously published on the 'tipping point' in online education, quality and cost, 'time' in online teaching.

Before joining UMUC, Professor SchWeber was the national Training Director in the Council of Better Business Bureaus' Mediation and Arbitration Division, supervising the training staff and revising the training model. It was here that she got her first experience with managing at a distance, since the trainers traveled three weeks of each month. She came to the CBBB after leaving a tenured teaching position in Criminal Justice at Buffalo State College (SUNY). She moved conflict resolution in the 1980s while teaching criminal justice, because the nascent field allowed for resolution of differences, a much more optimistic vision than is possible in criminal justice. She was trained in disability conflict mediation which led to her interest in accessibility. Currently, she mediates cases from the Washington D.C. U.S. Attorney's office.

Dr. SchWeber has been teaching in the United States and abroad for almost three decades. She has been honored as a SUNY Faculty Scholar, and is the recipient of Fulbright scholarships in Israel and Namibia. A native of France, Claudine SchWeber is delighted to see global involvement in e-learning, change and conflict resolution. 